\title{
Early detection of Huntington's disease. Blink reflex and levodopa load in presymptomatic and incipient subjects
}

\author{
ANGEL ESTEBAN, DOLORES, MATEO, AND \\ SANTIAGO GIMÉNEZ - ROLDÁN
}

\begin{abstract}
From the Laboratory of Clinical Neurophysiology and Department of Neurology, Ciudad Sanitaria Provincial, Madrid, Spain
\end{abstract}

SUMMARY The R2 response on the blink reflex was found to be abnormal in seven out of 17 Huntington's disease descendants. Such abnormalities were present in four untreated subjects and in three further subjects after administration of a single oral dose of levodopa-carbidopa. An increase in latency and differential latency (four cases), or in a single one of these parameters (three cases) were the abnormalities found, resembling findings in four incipient cases detected during routine family surveys. Continuous administration of levodopa-carbidopa over a 10-20 day period did not induce new characteristics in the blink reflex, nor increase those detected previously, and no case developed chorea. We suggest that the analysis of the blink reflex after a single oral levodopacarbidopa dosage could provide an objective and quantifiable method for the detection of individuals at risk for Huntington's disease.

Huntington's disease (HD) is due to a dominant gene of high penetrancy, yet the presence or absence of this abnormal gene can not usually be ascertained until obvious physical signs appear in the affected individual. Numerous predictive tests have been developed, but at present none is definitely reliable. $^{12}$ Oral levodopa increases chorea in affected patients through altered striatal response to dopamine. ${ }^{3}$ There are no data to show at which age this abnormal susceptibility develops but Klawans et $a l^{4} 5$ reported that onethird of presymptomatic HD descendants developed transient facial or limb dyskinesias or both after receiving oral levodopa and assumed that they would later develop the disease. Mainly because of uncertainty as to how to interpret these results, these investigators now rarely, if ever, use this test. ${ }^{2}$

Various parameters of the late response (R2) of the electrically evoked blink reflex are abnormal in $\mathrm{HD}^{6-8}$ and previous data suggested that once changes can be demonstrated even in early in-

Address for reprint requests: Dr Angel Esteban, Laboratory of Clinical Neurophysiology, Ciudad Sanitaria Provincial, Dr Esquerdo, 46, Madrid-30, Spain.

Accepted 20 July 1980 cipient cases. Levodopa is known to modify this reflex; its pattern in Parkinson's disease is reversed by treatment. ${ }^{910}$ It appeared that in presymptomatic subjects at risk of HD submitted to a levodopa predictive test, the simultaneous examination of the blink reflex possibly would provide a more sensitive and quantifiable method of detection than the simple visual search for choreic movements.

In this study, $17 \mathrm{HD}$ descendants were observed for the presence of dyskinesias and the blink reflex pattern before and after a levodopa load, and were compared to four incipient cases and normal controls studied under similar conditions.

\section{Methods}

\section{Ethical guidelines}

The use of a predictive test for an incurable disease such as HD is a matter of controversy. While some have instigated investigations requiring cooperative effort, ${ }^{45}$ others feel them unjustified mainly because the lack of an effective treatment and the impression that at-risk subjects prefer to live in the hope of being unaffected. ${ }^{11}$ In practice, however, the right of an individual to be fully informed with all the information available, and subsequently to make a personal choice cannot be overlooked. The ethical 
guidelines in the design of the present investigation were based on two crucial points. First, a full yet compassionate discussion of the information about the consequences and uncertainties inherent in the procedure was given, in such a way to allow a personal decision based upon solid grounds. Then, if the results of the test were positive, the individual received continuous supportive counselling to sustain his emotional needs and demands for further information and medical help. All families involved in this study were contacted by the Spanish Group of the Committee to Combat Hunington's Disease.

Once the diagnosis was established in the propositus and the family tree outlined, at-risk subjects were individually informed of the genetic consequences of the disease, the lack of any effective treatment at present and about the research project. The tentative nature of the results for predicting the risk for the future development of the condition was anticipated as well as the need of future retesting in the years to come to validate the results. It was announced that the effect of levodopa should be on the electrophysiological aspects of the study, but that there was a risk of inducing transitory involuntary movements. Subjects freely expressed their personal decision only after a second attendance; in case 10, a 9 year old girl, the decision was assumed by her guardian.

\section{Groups involved}

Three groups of subjects were studied (table 1). Normal volunteers (group A) comprised 20 individuals (nine men and 11 women) with a mean age of 30.5 years (range, 12 to 51 years). HD offspring group (group B) consisted of 17 subjects in whom one parent had had a definite diagnosis of the disease. There were eight men and nine women whose mean age was 28.8 years (range, nine to 58 years). Four subjects (two men and two women) formed the incipient HD group (group C) having a mean age of 40.5 years (range, 23 to 50 years). At this time they all had minimal, yet undisputable choreic movements, usually only in the face and hands; because of this, their relatives were already suspicious of the diagnosis in two cases, but they were unaware in the others.

Levodopa load tests

A single oral dose of combination of carbidopa- levodopa in one to ten ratio (Sinemet-25/250) was given as an acute test. The chronic test consisted of a stable dose of $1 \mathrm{~g}$ of levodopa per day (plus $100 \mathrm{mg}$ of carbidopa) for at least four days, this having being achieved through gradual increments over a 10 to 20 day period (table 1). Seven subjects of group A received a mean dose of levodopa of $390 \mathrm{mg}$ (range 350 to $500 \mathrm{mg}$ ) in the acute test and a mean total dose of $10 \mathrm{~g}$ in the chronic test, ranging from $7 \cdot 25$ to $14.35 \mathrm{~g}$. In group B, 15 individuals underwent the acute test (mean dose of $430 \mathrm{mg}$, ranging from 200 to $500 \mathrm{mg}$ ) and 11 had the chronic test (mean total dose of $9 \cdot 2 \mathrm{~g}$, ranging from $5 \cdot 25$ to $13 \mathrm{~g}$ ). In group $C$, three cases were submitted to the acute test, receiving a mean dose of $415 \mathrm{mg}$ (range, 375 to $500 \mathrm{mg}$ ).

\section{Blink reflex}

Percutaneous alternating electric shocks were delivered to the supraorbital nerve at its emergence on both sides. Responses were detected by means of coaxial needle electrodes inserted at the outer third of both lower eyelids. A Medelec MS5 electromyography device was used for recording. Quadrangular wave stimuli were of fixed duration $(0.5 \mathrm{~ms})$, but the intensity required to produce a well-defined $R 1$ response varied for each subject (25-100 volts). Five responses were obtained, interval between the electrical shocks being greater than $15 \mathrm{~s}$. The parameters of the late (R2) response were evaluated as described in a previous paper. ${ }^{6}$ In short, the latency was defined as the mean value of both maximal and minimal values of the ipsilateral responses. Differential latency was defined as the difference in latency between the $\mathbf{R} 2$ response obtained ipsilateral and contralateral to the stimulated side; its mean value was similarly obtained. The habituation index was expressed as the frequency of stimulation at which the last ipsilateral $R 2$ response, after a series of 10 consecutive stimuli, had a value (amplitude per duration) of less than 20 per cent of that in the first (it was measured independently on each side). Basal trends were obtained from every subject, and the second was reported forty to ninety minutes after levodopa ingestion in the acute test, care being taken to keep the electrodes in place. Finally, a third examination was carried out while the subject was taking levodopa chronically. The presence of abnormal involuntary

Table 1 Mean age of normal controls, Huntington's disease unaffected offspring and incipient cases, and mean total L-dopa dosage (given with carbidopa) in load tests

\begin{tabular}{|c|c|c|c|c|c|c|c|c|c|c|}
\hline & \multicolumn{3}{|c|}{ Normal controls } & \multicolumn{4}{|c|}{$\begin{array}{l}\text { Huntington's disease } \\
\text { Descendants at risk }\end{array}$} & \multicolumn{3}{|c|}{ Incipient Huntington's disease } \\
\hline & $N$ & $\begin{array}{l}\text { Mean age } \\
(y r)\end{array}$ & $\begin{array}{l}\text { L-dopa total dose } \\
\text { mean (range) }\end{array}$ & $\bar{N}$ & $\begin{array}{l}\text { Mean age } \\
(y r)\end{array}$ & $\begin{array}{r}L-d o \\
\text { mea }\end{array}$ & $\begin{array}{l}\text { pa total dose } \\
n \text { (range) }\end{array}$ & $\bar{N}$ & $\begin{array}{l}\text { Mean age } \\
(y r)\end{array}$ & $\begin{array}{l}\text { L-dopa total dose } \\
\text { mean (range) }\end{array}$ \\
\hline $\begin{array}{l}\text { Basal } \\
\text { Acute test (mg) } \\
\text { Chronic test (g) }\end{array}$ & $\begin{array}{l}20 \\
7 \\
6\end{array}$ & $\begin{array}{l}30 \\
31 \cdot 7 \\
30\end{array}$ & $\begin{array}{l}390(350-500) \\
10(7 \cdot 25-14 \cdot 3)\end{array}$ & $\begin{array}{l}17 \\
15 \\
11\end{array}$ & $\begin{array}{l}28 \cdot 8 \\
26 \cdot 5 \\
25 \cdot 8\end{array}$ & $\begin{array}{l}430 \\
9 \cdot 2\end{array}$ & $\begin{array}{c}- \\
(200-500) \\
(5 \cdot 25-13)\end{array}$ & $\begin{array}{l}4 \\
3 \\
-\end{array}$ & $\begin{array}{c}40 \cdot 5 \\
37 \cdot 6 \\
-\end{array}$ & $415(\overline{375-500)}$ \\
\hline
\end{tabular}

$\mathrm{N}=$ number of cases 
movements, as well as the ability to forcefully maintain eyelid occlusion and tongue protrusion was assessed before every electrophysiological recording.

\section{Statistical evaluation}

Results were statistically analysed by student's $t$-test.

\section{Results}

Levodopa-induced involuntary movements No normal control or HD descendant developed clinically evident involuntary movements while taking levodopa acutely or chronically. On close inspection case 2 in group $\mathbf{B}$ had minimal facial grimacing at the end of the chronic test and case 14 (group B) showed some inability to maintain the eyelids tightly closed, but we felt that this probably was due to anxiety. In contrast, two out of the three incipient patients given a single oral dose of levodopa developed a marked enhancement of chorea, although no changes were seen in the third patient.

Blink reflex Values from different $\mathrm{R} 2$ response parameters in all three groups are expressed in table 2. No differences from the normal controls were found after acute or chronic levodopa ingestion. Mean basal valv in HD descendants did not differ from control values $(p>0.05)$, and they were similar also after either form of levodopa load, both when compared to their own basal values or to those from normal subjects.

When individually analysed (table 3 ), four out of $17 \mathrm{HD}$ descendants showed an abnormal blink reflex pattern in basal conditions (cases 1 , 5, 7 and 15). After the acute levodopa test, an increase in the severity of the previous abnormalities occurred in case 1 , and two further cases (cases 4 and 16) became abnormal. After

Table 2 Basal blink reflex and after acute or chronic administration of levodopa (carbidopa) (mean \pm 1 SD)

\begin{tabular}{|c|c|c|c|c|}
\hline & Latency & $\begin{array}{l}\text { Differential } \\
\text { latency }\end{array}$ & $\begin{array}{l}\text { Habituation } \\
\text { index }\end{array}$ & $P$ \\
\hline \multicolumn{5}{|l|}{$\begin{array}{l}\text { Normal } \\
\text { Controls }\end{array}$} \\
\hline $\begin{array}{l}\text { Basal } \\
\text { Acute test } \\
\text { Chronic test }\end{array}$ & $\begin{array}{l}31 \pm 2 \cdot 85 \\
31 \cdot 5 \pm 3 \cdot 1 \\
29 \cdot 5 \pm 3 \cdot 1\end{array}$ & $\begin{array}{l}2 \cdot 46 \pm 1.92 \\
3 \cdot 03 \pm 2 \cdot 43 \\
2 \cdot 29 \pm 1.95\end{array}$ & $\begin{array}{l}0.71 \pm 0.25 \\
0.58 \pm 0.2 \\
0.8 \pm 0.18\end{array}$ & $\begin{array}{l}- \\
>0.05 \\
>0.05\end{array}$ \\
\hline \multicolumn{5}{|c|}{ HD offspring } \\
\hline $\begin{array}{l}\text { Basal } \\
\text { Acute test } \\
\text { Chronic test }\end{array}$ & $\begin{array}{l}31 \cdot 8 \pm 2 \cdot 9 \\
32 \cdot 05 \pm 3 \cdot 2 \\
30 \cdot 7 \pm 3 \cdot 3\end{array}$ & $\begin{array}{l}2 \cdot 06 \pm 3 \cdot 16 \\
2 \cdot 45 \pm 4 \cdot 79 \\
2 \cdot 13 \pm 3 \cdot 57\end{array}$ & $\begin{array}{l}0.67 \pm 0.31 \\
0.66 \pm 0.4 \\
0.62 \pm 0.29\end{array}$ & $\begin{array}{l}>0.05 \\
>0.05 \\
>0.05\end{array}$ \\
\hline \multicolumn{5}{|c|}{ Incipient HD } \\
\hline Basal & $38 \cdot 1 \pm 2 \cdot 3^{*}$ & $4 \cdot 18 \pm 3 \cdot 9 \dagger^{*}$ & $0.48 \pm 0.03 \ddagger$ & $\begin{array}{l}<0.001^{*} \\
>0.05 \dagger\end{array}$ \\
\hline Acute test & $39 \cdot 8 \pm 4 \cdot 3^{*}$ & $5 \cdot 75 \pm 6 \cdot 6 t^{*}$ & $0.47 \pm 0.07 \ddagger$ & $<0.05 \ddagger$ \\
\hline
\end{tabular}

P, when compared with the basal values of normal control subjects. HD-Huntington's disease. the chronic levodopa test, no increase in the severity of the previously recorded abnormalities was found and no new abnormalities appeared in the HD descendants. A further subject (case 10), which was the only one not examined under basal conditions because of her young age, appeared abnormal after the acute levodopa load. Both latency and differential latency were the abnormal parameters recorded from four cases, while the other three had abnormalities in only one of these parameters (figure). Furthermore, each of these seven cases had a habituation index value below the mean in control subjects $(0 \cdot 71)$. None of the three parameters evaluated differed from normal controls, before or after levodopa in the other 10 descendants. The two individuals (cases 2 and 14, table 3) in which the presence of levodopa-induced dyskinesias was questioned clinically, experienced no changes in their blink reflex patterns. The mean age of HD descendants having an abnormal blink reflex (28.4 years) was similar to those having normal values (29.3 years). A nine year old girl, who was the youngest subject examined from group B, had also the more severe degree of abnormal blink reflex. The onset of HD in her mother was at 23 years and several other affected members from her family, including case 3 of group C, also had an unusually early onset of the disease.

Mean latency and habituation index values from these four cases of incipient HD (group C) differed from normal controls $(p<0.001$ and $p<0.05$, respectively), both before and after the acute levodopa provocative test (table 2). Basal individual latency values also were greater than the maximum normal value $(36.7 \mathrm{~ms})$ from the control group (table 4; figure). A further shift towards abnormality was obtained after the acute administration of levodopa and, in addition, the differential latency also became abnormal in two cases, in parallel with a levodopa-induced deterioration of the choreic movements. The patient in whom there was no appreciable increase of the choreic movements on levodopa (case 2, table 4) also was the only one in which the blink reflex pattern remained unmodified.

\section{Discussion}

The incipient HD group consisted of four fully employed individuals, unaware of their illness which was detected during routine family surveys. Nevertheless, it was obvious to the experienced neurologist that they had mild yet characteristic choreic movements. This group had a R2 response of their blink reflex modified in a 
Table 3 Basal blink reflex in Huntington's disease offspring and after L-dopa/carbidopa load tests $\dagger$

\begin{tabular}{|c|c|c|c|c|c|c|c|c|c|}
\hline \multirow[t]{2}{*}{ Case/age (yr) } & \multicolumn{3}{|l|}{ Basal } & \multicolumn{3}{|c|}{ Acute test } & \multicolumn{3}{|c|}{ Chronic test } \\
\hline & $\bar{L}$ & $D L$ & $H I$ & $L$ & $D L$ & $\overrightarrow{H I}$ & $L$ & $D L$ & $\overline{H I}$ \\
\hline \multirow{2}{*}{$2 \mathrm{LCN} 17$} & & & $0 \cdot 7$ & $38^{*}$ & $-6^{*}$ & 0.5 & 33 & $-2^{*}$ & $0 \cdot 6$ \\
\hline & 30 & $\begin{array}{l}6 \\
1 \cdot 5\end{array}$ & $\begin{array}{l}0.7 \\
0.5\end{array}$ & $\begin{array}{l}28 \cdot 5 \\
30\end{array}$ & 2 & $0 \cdot 5$ & 28 & 3 & 0.5 \\
\hline \multirow{2}{*}{$3 \mathrm{ECN} 30$} & 30 & 2 & $\begin{array}{l}0.3 \\
0.5\end{array}$ & $\begin{array}{l}30 \\
29\end{array}$ & $\begin{array}{l}3 \\
3 \cdot 5\end{array}$ & $\begin{array}{l}0.5 \\
0.45\end{array}$ & $\begin{array}{l}28 \\
30\end{array}$ & $1 \cdot 5$ & $\begin{array}{l}0.5 \\
0.5\end{array}$ \\
\hline & 31 & $1 \cdot 5$ & 0.5 & 30 & 3 & 0.45 & 30 & 1 & 0.5 \\
\hline \multirow[t]{2}{*}{4 JLCN 27} & $26 \cdot 5$ & 5 & 0.5 & $26 \cdot 5$ & 3 & 0.5 & $26 \cdot 5$ & $-1 \cdot 5^{*}$ & 0.5 \\
\hline & 27 & - & 0.5 & 28 & $-2 \cdot 5^{*}$ & 0.5 & 27 & $-2^{*}$ & 0.5 \\
\hline \multirow{2}{*}{$5 \mathrm{CCN} 19$} & 33 & $-1 \cdot 5^{*}$ & 0.5 & 31 & 4 & 0.5 & $29 \cdot 5$ & $3 \cdot 5^{*}$ & 0.25 \\
\hline & 29 & -0.5 & $0 \cdot 5$ & $31 \cdot 5$ & $-2^{*}$ & 0.5 & 31 & $-2^{*}$ & $0 \cdot 25$ \\
\hline \multirow[t]{2}{*}{6 PSP 52} & $33 \cdot 5$ & $3 \cdot 5$ & 0.5 & - & - & - & 36 & 5 & $0 \cdot 5$ \\
\hline & 31 & 4 & 1 & - & - & - & 36 & $5 \cdot 5$ & 0.5 \\
\hline \multirow{2}{*}{7 JSP 45} & 33 & 1 & 0.5 & $32 \cdot 5$ & 1 & 0.45 & - & - & - \\
\hline & $37 *$ & 0.5 & $0 \cdot 5$ & $35 \cdot 5$ & 0 & 0.45 & - & - & - \\
\hline \multirow{2}{*}{8 AMS 30} & 30 & $2 \cdot 5$ & $0 \cdot 8$ & $28 \cdot 5$ & -1 & 1 & - & - & - \\
\hline & 30 & $1 \cdot 5$ & 1 & $29 \cdot 5$ & 4 & 2 & - & - & - \\
\hline \multirow{2}{*}{9 МСМ 19} & $33 \cdot 5$ & 1.5 & 0.5 & $32 \cdot 5$ & $4 \cdot 5$ & 0.5 & - & - & - \\
\hline & $31 \cdot 5$ & 4 & $0 \cdot 5$ & 33 & 0 & 0.5 & - & - & - \\
\hline \multirow[t]{2}{*}{10 DCM 9} & - & - & - & $40^{*}$ & $9 \cdot 5^{*}$ & - & - & - & - \\
\hline & - & - & - & $41^{*}$ & 2 & - & - & - & - \\
\hline \multirow{2}{*}{11 MSS 26} & $35 \cdot 5$ & $4 \cdot 5$ & $0 \cdot 5$ & 30 & $3 \cdot 5$ & 0.5 & $32 \cdot 5$ & 1 & 0.5 \\
\hline & $32 \cdot 5$ & -0.5 & 0.5 & 35 & 0 & 0.5 & $32 \cdot 5$ & 2 & 0.5 \\
\hline \multirow[t]{2}{*}{12 JAJP 21} & 30 & 1 & $1 \cdot 5$ & $32 \cdot 5$ & 3 & $1 \cdot 5$ & 31 & 1 & $1 \cdot 5$ \\
\hline & 32 & 3 & 1.2 & 32 & 2 & $1 \cdot 2$ & 32 & $2 \cdot 5$ & $1 \cdot 2$ \\
\hline \multirow[t]{2}{*}{13 AIJP 22} & 30 & $2 \cdot 5$ & 1 & $30 \cdot 5$ & 1 & 1 & 27 & 1 & 1 \\
\hline & 29 & 0 & 1 & $29 \cdot 5$ & $i$ & 1 & $28 \cdot 5$ & -0.5 & $i$ \\
\hline \multirow{2}{*}{14 PJP 18} & 32.5 & 2 & 1 & 32 & -1 & 0.7 & 28.5 & 2 & 0.7 \\
\hline & 31 & 0 & 1 & $32 \cdot 5$ & 0.5 & 0.5 & 27 & $5 \cdot 5$ & 0.7 \\
\hline \multirow[t]{2}{*}{15 VSS 26} & $35 \cdot 5$ & $10^{*}$ & 0.5 & 34 & $7^{*}$ & 0.45 & $32 \cdot 5$ & $7 \cdot 5^{*}$ & $0 \cdot 4$ \\
\hline & $40 \cdot 5^{*}$ & $-6^{*}$ & 0.5 & 34 & $-1 \cdot 5^{*}$ & 0.45 & $39 \cdot 5 *$ & -1 & $0 \cdot 5$ \\
\hline \multirow[t]{2}{*}{16 FJP 45} & $30 \cdot 5$ & $4 \cdot 5$ & 0.6 & 32 & $9^{*}$ & 0.51 & - & - & - \\
\hline & $33 \cdot 5$ & $2 \cdot 5$ & 0.5 & $36 \cdot 7^{*}$ & 2 & 0.5 & - & - & - \\
\hline \multirow[t]{2}{*}{17 LMG 58} & $30 \cdot 5$ & 0.5 & 0.5 & - & - & - & - & - & - \\
\hline & 33 & 0.5 & 0.5 & - & - & - & - & - & - \\
\hline
\end{tabular}

†Values from right (upper) and left (lower) sides in each case $\mathrm{L}=$ Latency (in $\mathrm{ms}$ ); $\mathrm{DL}=$ Differential latency (in $\mathrm{ms}$ ); $\mathrm{HI}=\mathrm{Habituation}$ index. * = Abnormal values, beyond normal control mean basal values $\pm 2 \mathrm{SD}$.

Negative values of DL means that R2 response contralateral to the stimulated side appears earlier than the ipsilateral one.

Figure Mean values $\pm 2 S D$ of latency and differential latency of the $R 2$ response of the blink reflex on both sides from a sample of 20 healthy subjects are represented within the dotted line (rectangle). Seven out of 17 Huntington's disease descendants and the four incipient cases are placed outside. No case with abnormal blink reflex findings had a habituation index value over 0.5 . Values represented were those which displayed the greatest deviation from normality, whether or not under basal conditions or after a levodopa-carbidopa administration.

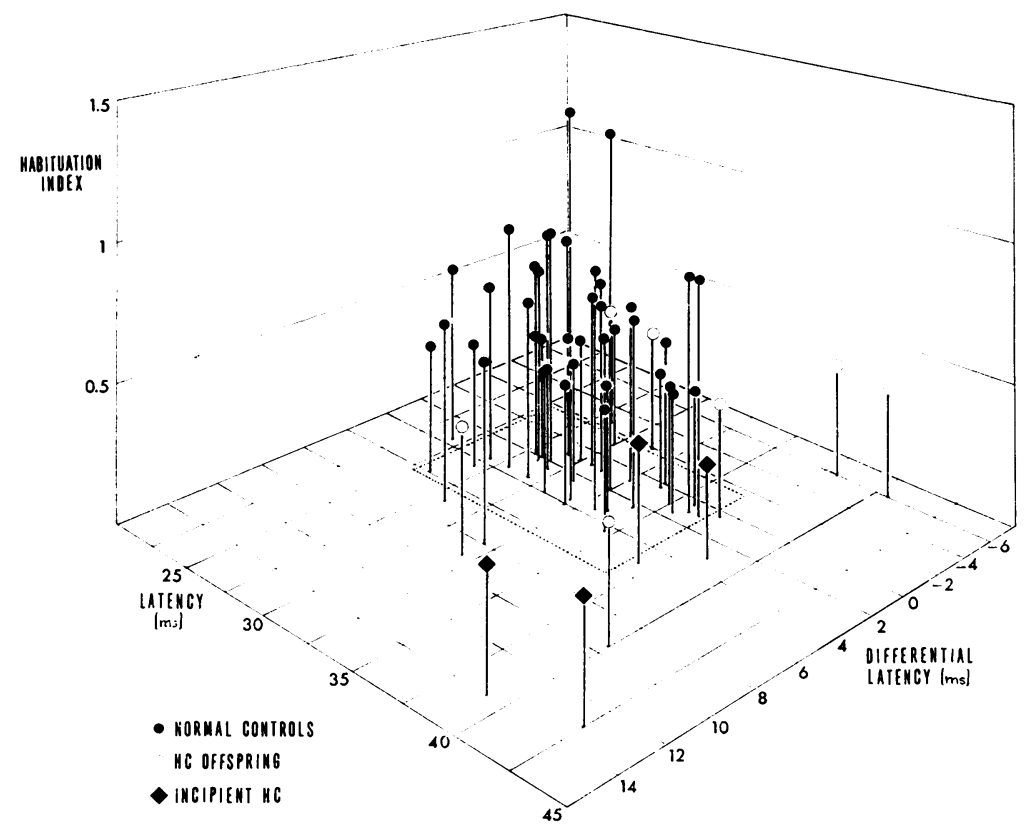


Table 4 Blink reflex in incipient Huntington's disease cases

\begin{tabular}{|c|c|c|c|c|c|c|}
\hline \multirow[t]{2}{*}{ Case/age (yr) } & \multicolumn{3}{|l|}{ Basal } & \multicolumn{3}{|c|}{ Acute L-dopa/carbidopa test } \\
\hline & Latency & $\begin{array}{l}\text { Differential } \\
\text { latency }\end{array}$ & Habituation index & Latency & $\begin{array}{l}\text { Differential } \\
\text { latency }\end{array}$ & Habituation index \\
\hline 1 AGM 49 & $\begin{array}{l}37^{*} \\
38 \cdot 5^{*}\end{array}$ & $\begin{array}{l}3 \\
3\end{array}$ & $\begin{array}{l}0.5 \\
0.4\end{array}$ & - & - & - \\
\hline 2 JLGF 40 & $\begin{array}{l}34 \\
37^{*}\end{array}$ & $\begin{array}{l}4 \\
5\end{array}$ & $\overline{0.5}$ & $\begin{array}{l}36 \\
35\end{array}$ & $\begin{array}{l}\overline{4} \\
4\end{array}$ & $\overline{0}-5$ \\
\hline 3 TMM 23 & $\begin{array}{l}37 \cdot 5^{*} \\
39 *\end{array}$ & $\begin{array}{l}5 \cdot 5 \\
1\end{array}$ & $\begin{array}{l}0.5 \\
0.5\end{array}$ & $\begin{array}{l}39 * \\
40 \cdot 5^{*}\end{array}$ & $14 *$ & $\begin{array}{l}0.5 \\
0.5\end{array}$ \\
\hline 4 MER 50 & $\begin{array}{l}40^{*} \\
42 \cdot 5^{*}\end{array}$ & $\begin{array}{l}12 \cdot 5^{*} \\
-0.5\end{array}$ & $\begin{array}{l}0.5 \\
0.5\end{array}$ & $\begin{array}{l}42 \cdot 5^{*} \\
46^{*}\end{array}$ & $\begin{array}{l}13 * \\
-3 \cdot 5 *\end{array}$ & $\begin{array}{l}0.5 \\
0.35\end{array}$ \\
\hline
\end{tabular}

Values from right (upper) and left (lower) sides in each case. Latency and differential latency in ms.

*=Abnormal values, beyond normal control mean basal values \pm 2 SD

similar way to those in patients with advanced disease. ${ }^{6}$ The failure of Ferguson $e t a l^{8}$ to demonstrate blink reflex abnormalities in their young patients could be explained on the basis that latencies and differential latencies, which were the most severe abnormalities usually found in our series, were not examined. Similar to overt $\mathrm{HD}^{3}$ all but one of our incipient cases deteriorated in the severity of chorea when a single oral levodopa dose was administered. Parallel to the enhancement of chorea, there was a further shift toward abnormality of the previously altered R2 patterns.

Seven out 17 individuals from the HD descendants group (41\%) displayed significant abnormalities in their blink reflex. The impaired parameters were latency and differential latency, similar to incipient and advanced HD patients. The abnormalities occurred for both parameters in $23.5 \%$ of the cases, while in the other $17.6 \%$ it was for one parameter only. The abnormalities were already present under basal conditions in four cases while in the other three they were shown after the acute administration of levodopa (case 10, because of her early age, was examined only under the later condition). In normal subjects, acute or chronic administration of HD descendant caused no change in the blink reflex. As no developed levodopa-induced involuntary movements, the present results suggest that both the blink reflex abnormalities and their modifications by levodopa occur well before the appearance of choreic movements, either spontaneous or drug-induced. The effects of acute administration of levodopa in HD descendants were unmodified after two to three weeks of levodopa intake, so it appears that the chronic test did not provide any practical advantage over the acute test. None of our $11 \mathrm{HD}$ descendants developed overt or definite choreic movements while under levodopa given over a 10 to 20 days period. These results do not agree with those of Klawans et $a l,{ }^{45}$ who reported that about one-third of their HD descendants developed mild chorea, mainly in the facial area, while on chronic levodopa. The dose schedules were similar in both studies and cannot account for this discrepancy. There are no other references in the literature regarding the effect of levodopa as a provocative test to induce chorea in presymptomatic subjects. Cawein and Turney ${ }^{12}$ and Husquinet et $a l^{13}$ induced a clearcut increase in the severity of chorea in individuals who had already mild abnormal involuntary movements before any treatment with levodopa (as in our incipient group C).

We plan to retest and publish the results after a five year period of observation of the HD descendants. Either an increase in the electrophysiological abnormalities already detected in still clinically unaffected subjects, or the emergence of the disease during that time may occur, but it may take much longer to decide whether the test does give reliable predictive information. We would encourage other groups to undertake the present investigation and to check its reproductibility in individuals at risk demanding a predictive test. Not only does it provide objective quantifiable abnormalities, but it avoids the unwanted situation of prematurely facing the subject with the image of his eventual illness by inducing chorea.

\section{References}

1 Goodman RM, Ashkenazi YE, Adam A, Greenfield G. Thoughts on the early detection of Huntington's Chorea. In: Advances in Neurology, vol 1. New York: Raven Press, 1973: 273-85.

2 Paulson GW. Predictive tests in Huntington's Disease. In: Yahr MD, ed. The Basal Ganglia. New York: Raven Press, 1976: 317-29.

3 Klawans HL. A pharmacologic analysis of Huntington's chorea. Eur Neurol 1970; 4:148-63.

4 Klawans HL, Paulson GW, Ringel SP, Barbeau 
A. Use of L-dopa in the detection of presymptomatic Huntington's chorea. N Engl J Med 1972; 286:1332-4.

5 Klawans HL, Paulson GW, Ringel SP, Barbeau A. The use of L-dopa in the presymptomatic detection of Huntington's chorea. In: Advances in Neurology, vol 1. New York, Raven Press, 1973: 295-300.

6 Esteban A, Giménez-Roldán S. Blink reflex in Huntington's chorea and Parkinson's disease. Acta Neurol Scand 1975; 52:145-57.

7 Caraceni T, Aranzini G, Spreafico R, Negri S, Broggi G, Girotti F. Study of the excitability cycle of the blink reflex in Huntington's chorea. Eur Neurol 1976; 14:465-72.

8 Ferguson IT, Lenman JAR, Johnston BB. Habituation of the orbicularis oculi reflex in dementia and dyskinetic states. $J$ Neurol Neuro- surg Psychiatry 1978; 41:824-8.

9 Penders CA, Delwaide PJ. Blink reflex studies in patients with Parkinsonism before and during therapy. J Neurol Neurosurg Psychiatry 1971; 34:674-8.

10 Messina C, Di Rosa AE, Tomasello F. Habituation of blink reflexes in Parkinsonian patients under levodopa and amantadine treatment. $J$ Neurol Sci 1972; 17:141-8.

11 Emery AEH. Whether or not predictive tests? Neurology (Minneap) 1980; 30:345-6.

12 Cawein M, Turney F. Test for incipient Huntington's chorea. $N$ Engl J Med 1971; 284:504.

13 Husquinet H, Franck G, Vranckx C. Detection of future cases of Huntington's chorea by the LDopa load test: Experiment with two monozygotic twins. In: Advances in Neurology, vol 1. New York: Raven Press, 1973: 301-10. 